\title{
PENGARUH PEMBERIAN BUAH TERHADAP GEJALA DEPRESI, SUASANA HATI (MOOD) DAN VITALITAS PADA REMAJA PUTRI DI PONDOK PESANTREN ASSIDDIQIYAH
}

\author{
The Effect of Giving Fruit on Depression Symptoms, Mood, and Vitality among Adolescent Girls In \\ Assiddiqiyah Islamic Boarding School \\ Asri Nur Latifah ${ }^{1}$, Khairizka Citra Palupi ${ }^{1}$, Mertien Sapang ${ }^{1}$ \\ ${ }^{1}$ Departemen IImu Gizi Universitas Esa Unggul, Jakarta \\ E-mail: asrinurlatifah@gmail.com
}

\begin{abstract}
Adolescence is the transition period of the development of physical and mental health that may induce depression. Being adolescent girls shows a higher risk of depression than adolescent men. Fruit consumption has been identified may alleviate depression. Thus we aim to investigate the effect of giving fruit consumption on depressive symptoms, mood, and vitality among adolescent girls. This research method uses Quantitative-Experiments with the control group. The treatment group was given two servings of fresh fruit/day for 14 days while the control group maintained a diet. The filling out of the questionnaire was done at night before going to bed. The total sample used in this study was 60 students. The result shows a significant decrease of depressive symptoms $(p$-value $<0.05)$ at the pre-test and posttest of $14.47 \%$ among the treatment group. However, there was no difference in mood scores among the treatment group. There was a significant increase in post-test scores of vitality in the treatment group (pvalue $<0.05$ ). In the independent statistical test, the sample $t$-test had a difference between depressive symptom scores $(p$-value $<0.01)$ and mood $(p$-value $<0.05)$ in both groups. In conclusion, giving fruit may alleviate symptoms of depression, mood, and vitality among adolescent girls.
\end{abstract}

Keywords: fruit, symptoms of depression, mood, vitality, adolescent girls

\section{ABSTRAK}

Masa remaja adalah tahap transisi dari perkembangan kesehatan fisik dan mental yang dapat memicu depresi. Remaja putri menunjukkan risiko depresi lebih tinggi dibandingkan remaja pria. Konsumsi buah diketahui mampu memperbaiki kondisi depresi. Oleh karena itu, penelitian kami bertujuan untuk mengetahui pengaruh pemberian buah terhadap gejala depresi, suasana hati (mood), dan vitalitas remaja putri. Metode penelitian ini menggunakan kuantitatif-eksperimen dengan kelompok kontrol. Kelompok perlakuan diberikan buah segar sebanyak 2 porsi/hari selama 14 hari sedangkan kelompok kontrol mempertahankan pola makan. Pengisian kuesioner dilakuakan di malam hari sebelum tidur. Total sampel yang digunakan pada penelitian ini sebanyak 60 remaja putri. Hasil penelitian menunjukkan perbaikan signifikan gejala depresi sebesar 14,47 persen pada kelompok perlakuan ( $p$-value $<0,05$ ). Namun tidak ada perbedaan pada skor susana hati (mood) pada kelompok perlakuan. Terjadi peningkatan skor vitalitas yang signifikan pada kelompok perlakuan $(p$-value $<0,05)$. Berdasarkan independen sample t-test, terdapat perbedaan skor gejala depresi $(p$-value $<0,01)$ dan suasana hati $($ mood) $(p$-value $<0,05)$ pada kedua kelompok. Kesimpulan dari penelitian ini adalah pemberian buah mampu memperbaiki gejala depresi, suasana hati (mood) dan vitalitas pada remaja putri.

Kata kunci: buah, gejala depresi, suasana hati (mood), vitalitas, remaja putri

Doi: $10.36457 / g i z i n d o . v 44 i 1.466$

www.persagi.org/ejournal/index.php/Gizi_Indon 


\section{PENDAHULUAN}

$\mathrm{M}$ asa remaja adalah tahap transisi dari perkembangan kesehatan fisik dan mental ke masa dewasa. Pada masa remaja terjadi perkembangan hormonal, fisik, psikologis, dan sosial yang cepat dan memiliki dampak besar pada kehidupan selanjutnya. ${ }^{1-2}$ Menurut data Riskesdas tahun 2018, prevalensi depresi 6,1 persen pada usia 15 tahun ke atas dengan 91 persen tidak berobat. Sementara prevalensi gangguan mental emosional 9,8 persen pada usia lebih dari 15 tahun. yang ditunjukkan dengan gejala depresi dan kecemasan. ${ }^{3}$ Kemenkes memperkirakan jumlah penderita depresi akan bertambah dua kali lipat pada tahun 2030 yang berdampak pada penambahan beban negara dan penurunan produktivitas manusia untuk jangka panjang. ${ }^{4}$ Kesehatan mental menjadi salah satu permasalahan kesehatan yang signifikan di dunia, termasuk di Indonesia.

Anak perempuan $(36,33 \%)$ cenderung memiliki masalah emosional lebih sering dibandingkan anak laki-laki (12,96\%). ${ }^{2}$ Berdasarkan penelitian Arsita tahun 2016 yang dilakukan pada remaja putri pondok pesantren dan sekolah biasa di daerah Sukoharjo menemukakan bahwa tingkat depresi remaja putri penghuni asrama atau pesantren $(22,09 \%)$ lebih signifikan antara remaja penghuni asrama dengan sekolah biasa $(8,13 \%) .^{5}$ Hal ini didukung penelitian Krishnaveni et al. yang menyebutkan bahwa sebanyak 69,4 persen remaja mengalami depresi pada asrama putri di negara India. ${ }^{6} \mathrm{Di}$ asrama, semua penghuni terikat olah peraturan ketat. Peraturan ini memuat hal-hal tentang jam tertentu yang telah diatur, izin yang diberikan, kebiasaan dan larangan-larangan yang berlaku keras bagi penghuni asrama tanpa terkecuali. Penghuni asrama pun mempunyai tanggung jawab untuk mengurus asrama bersama. Hal tersebut membuat penghuni asrama hidup tidak sebebas remaja sekolah biasa. $^{7}$ Menurut penelitian Wuon et al. tahun 2016, 80 persen atau 4 dari 5 orang remaja yang tinggal di asrama mengungkapkan bahwa mereka merasa kurang nyaman karena merasa tertekan dengan peraturan yang ada serta kurangnya kasih sayang. ${ }^{8}$ Penelitian menunjukkan bahwa remaja putri dengan kecemasan secara signifikan tidak nyaman berada di asrama dibandingkan dengan remaja putri di sekolah biasa dengan odds rasio $4,77.6$

Banyak faktor yang mempengaruhi kesehatan mental diantaranya faktor genetik, sosial-ekonomi, status kesehatan, keluarga, lingkungan, pola aktivitas, pola tidur, dan pola makan.9-11 Penelitian terdahulu menyebutkan bahwa konsumsi sayuran dan buah-buahan mampu mengendalikan profil metabolisme seperti tekanan darah, kadar gula, kolesterol darah, kanker, mortilitas kardiovaskular, dan semua penyebab kematian serta memperpanjang usia hidup. ${ }^{12-15}$ Yang menarik, konsumsi sayur dan buah tidak hanya mengendalikan metabolisme dan kondisi fisik tetapi juga kondisi mental emosional seperti depresi, kecemasan, suasana hati (mood), kualitas hidup, dan kesehatan mental lainnya. ${ }^{16-}$ ${ }_{19}$ Gangguan mental emosional seperti depresi, suasana hati, dan vitalitas dapat dipengaruhi oleh neurotransmitter. Neurotransmitter yang berperan dalam mempengaruhi depresi dan suasana hati adalah naroadrenalin, dopamin dan serotonin. ${ }^{20}$ Perubahan dopamin menjadi noradrenalin membutuhkan vitamin $\mathrm{C}$ yang banyak terdapat di buah-buahan. ${ }^{21}$ Vitamin B6, B12, dan B9 yang terdapat dalam buah segar merupakan prekursor yang menyebabkan penurunan homosistein yang akan mempengaruhi depresi dan suasana hati dan kesehatan mental lainnya. 22,23 Hal tersebut terbukti oleh penelitian Carr et al. tahun 2013 melaporkan terdapat penurunan 38 persen $(p=$ 0,029 ) pada gangguan suasana hati (mood) dengan pemberian dua buah kiwi selama 6 minggu. ${ }^{16}$ Penelitian lain menyebutkan dengan konsumsi satu buah segar seperti apel dan pisang) sebagai cemilan setiap hari selama 10 hari dapat mengurangi kelelahan, depresi, kecemasan, kognitif, dibanding dengan konsumsi wafer coklat atau kripik kentang yang diuji cobakan kepada 100 mahasiswa. Pemberian buah memberikan hasil skor depresi lebih rendah dibandingkan dengan pemberian coklat atau kripik. ${ }^{18}$ Berdasarkan penelitian Brookie (2017) dengan intervensi pesan singkat yang berbasis internet dan pemberian sayur buah segar selama 2 minggu menunjukkan hasil bahwa pemberian intervensi sayur dan buah segar mampu meningkatkan vitalitas $(p=$ $0,006)$, semangat $(p=0,003)$, dan perilaku bersemangat $(p=0,006)$ dibandingkan dengan peserta yang hanya diberikan pesan singkat 
berbasis internet untuk mengokonsumsi sayur dan buah. ${ }^{19}$

Lebih dari 90 persen penduduk Indonesia di atas 10 tahun masih kurang mengonsumsi sayur dan buah. Berdasarkan data Riskesdas mengenai kurangnya konsumsi sayur dan buah pada tahun 2007 dan 2013 pada kelompok umur $\geq 10$ tahun tidak ada perubahan presentase yang signifikan. ${ }^{24-25}$ Sejumlah 93,5 persen kelompok umur $>10$ tahun masih kurang mengonsumsi sayur dan buah di tahun 2007 dan meningkat menjadi 95,5 persen pada tahun 2018. ${ }^{3}$ Data Riskesdas tidak membedakan secara jelas berapa presentase penduduk yang kurang mengonsumsi sayur dan kurang mengonsumsi buah. Adapun data dari Survei Konsumsi Makanan Individu tahun 2014, yang menyatakan bahwa proporsi penduduk Indonesia yang mengonsumsi sayur sebanyak $94,8 \%$ dan konsumsi buah sebanyak 33,2 persen, namun jumlahnya tidak sesuai anjuran dan bila dilihat dari kelompok umur, remaja adalah kelompok umur tertinggi yang kurang mengonsumsi sayur dan buah $(98,4 \%) .{ }^{26}$ Berdasarkan Pedoman Gizi Seimbang, konsumsi sayur dan buah dikategorikan 'cukup' jika memakan sayur dan buah minimal 5 porsi perhari atau setara dengan $400 \mathrm{~g}^{.12}$

Dari pemaparan data di atas dapat disimpulkan bahwa konsumsi buah segar dapat mempengaruhi kesehatan mental diantaranya gejala depresi, suasana hati (mood) dan vitalitas. Konsumsi buah terbukti mampu memperbaiki kesehatan fisik dan mental. ${ }^{12-19}$ Penelitian mengenai pengaruh pemberian buah terhadap kesehatan mental pada remaja yang berfokus pada gejala depresi, suasana hati (mood) dan vitalitas masih terbatas. Oleh karena itu, penelitian ini bertujuan untuk menganalisis pengaruh pemberian buah terhadap gejala depresi, suasana hati (mood) dan vitalitas pada remaja putri di Pondok Pesantren Assiddiqiyah, Jakarta Barat.

\section{METODE PENELITIAN}

Metode penelitian yang digunakan dalam penelitian ini menggunakan metode penelitian kuantitatif - eksperimen. Penelitian dilakukan pada Santriwati Pondok Pesantren Assiddiqiyah kelas 1 dan 2 Sekolah Menengah Atas, Jakarta Barat pada bulan Januari hingga Februari 2019. Untuk mengetahui penerimaan sampel terhadap intervensi sayur dan buah segar maka sebelumnya, peneliti melakukan pengambilan data awal pada 10 remaja putri, didapatkan hasil bahwa pemberian buah segar lebih diterima oleh seluruh panelis dibanding dengan pemberian sayur segar atau smoothie sayur buah. Rancangan yang digunakan dalam penelitian ini adalah rancangan pretest and posttest with control grup. Kelompok perlakuan (eksperimen) adalah kelompok yang mendapat penambahan pemberian buah potong segar sebanyak 2 porsi/hari selama 14 hari. Penetapan 2 porsi buah setiap hari sesuai Pedoman Gizi Seimbang dengan berat total 200 $\mathrm{gr}^{2}$ Sementara itu, kelompok pembanding (kontrol) adalah kelompok sampel yang mempertahankan pola makan. Sampel penelitian sebanyak 60 orang dimana 30 orang adalah kelompok kontrol dan 30 orang adalah kelompok perlakuan. Kriteria inklusi dari penelitian ini adalah 1) santriwati yang tinggal di asrama Pondok Pesantren Assiddiqiyah, 2) bersedia mengikuti penelitian, 3) berusia 15-18 tahun dan 4) tidak sedang menstruasi selama masa intervensi. Sementara kriteria eksklusi adalah 1) perokok aktif, 2) mengonsumsi obat anti depresi, 3) mempunyai penyakit kronis, 4) tidak menyukai buah, 5) alergi terhadap buah, dan 6) memiliki asam lambung tinggi. Penelitian ini juga telah lolos kaji etik Universitas Esa Unggul dengan nomor 0053-19.053/DPKEKEP/FINAL-EA/UEU/II?2019

Pada Proses Pengumpulan Data pertama tama dilakukan wawancara menggunakan instrument Semi-Quantitative Food Frequency Questionairre mengenai konsumsi sayur dan buah sebelum intervensi. Kemudian gejala depresi diukur menggunakan kuesioner CSE-D (Center for Epidemiologi Studies Depression).27 Berikutnya Suasana Hati (mood) diukur dengan kuesioner Positive Affect and Negative Affect Scale. ${ }^{28}$ Sementara itu, untuk data vitalitas diperoleh dari pengisian kuesioner Fatigue Scale. Kelompok perlakuan diberikan buah sebanyak 2 kali dalam sehari sebanyak 1 porsi/pemberian (@100 gr) sehingga kelompok perlakuan mendapat $200 \mathrm{gr} / \mathrm{hr}$. Jenis buah yang diberikan yaitu melon, semangka, pepaya, pisang ambon, jeruk, pear, buah naga, duku, nanas, belimbing, rambutan, salak, manggis, apel, dan jambu biji. Buah yang digunakan untuk intervensi dibersihkan, dipotong dan ditimbang. Sedangkan untuk kelompok kontrol 
dilakukan pemantauan konsumsi buah setiap hari selama 14 hari. Pada hari ke 0 dan 14 kuesioner gejala depresi, suasana hati (mood) dan vitalitas dan diisi pada malam hari sebelum tidur untuk melihat perubahan yang terjadi. Kami memilih asrama karena penyelenggaraan makanan terpusat, sehingga konsumsi makanan relative sama untuk semua anak. Untuk memastikan konsumsi buah, peneliti memberikan edukasi kepada responden sebelumnya dan memantau konsumsi buah semua responden satu persatu.

Analisis data menggunakan analisis univariat dan bivariate. Pada analisis univariat data dikelompokkan lalu diidentifikasi menggunakan tabel distribusi frekuensi. Sementara pada analisis bivariate, uji statistik yang digunakan adalah uji t. Uji t digunakan untuk melihat perubahan apakah setelah intervensi buah, responden menunjukkan perubahan skor depresi, suasana hati dan vitalitas serta untuk menginvestigasi apakah ada perbedaan selisih skor antar kelompok sebelum dan setelah diberikan intervensi.
HASIL

\section{Karakteristik Sampel}

Sampel yang diteliti pada penelitian ini sebanyak 60 orang yang merupakan santriwati Pondok Pesantren Assiddiqiyah Pusat, Jakarta. Terdapat terdapat sampel drop out sebanyak 2 $(6,7 \%)$, sedangkan drop out pada kelompok perlakuan sebanyak $4(13,3 \%)$ sampel. Selama proses intervensi pemberian buah, menunjukkan bahwa 97,93 persen subjek patuh atau menghabiskan buah yang diberikan dengan nilai minimum sebesar 88,57 persen. Tidak ada variasi makanan yang berarti karena sampel tinggal di asrama.

\section{Konsumsi Buah pada Responden Sebelum dan Sesudah Intervensi}

Berdasarkan Tabel 1 pada kelompok perlakuan diperoleh rata-rata konsumsi buah perhari sebelum intervensi sebanyak $15,21 \pm 15,78 \mathrm{gram} / \mathrm{hari}$, data sesudah intervensi sebanyak 201,35 $\pm 12,04$ gram/hari. Pada kelompok kontrol diperoleh rata-rata $17,27 \pm 13,32 \mathrm{~g} / \mathrm{hari}$ sebelum intervensi dan $31,00 \pm 19,65 \mathrm{~g} /$ hari sesudah intervensi.

Tabel 1

Distribusi Gejala Depresi Pada Responden Sebelum dan Sesudah Intervensi

\begin{tabular}{|c|c|c|c|c|c|}
\hline \multirow{2}{*}{\multicolumn{2}{|c|}{ Indikator }} & \multicolumn{2}{|c|}{ Kelompok Perlakuan $(n=26)$} & \multicolumn{2}{|c|}{ Kelompok Kontrol $(n=28)$} \\
\hline & & Pretest & Posttest & Pretest & Posttest \\
\hline \multicolumn{6}{|c|}{ Konsumsi Buah } \\
\hline - & Mean & 15,21 & 201,35 & 17,28 & 31,00 \\
\hline - & Std. Deviation & 15,79 & 12,047 & 13,32 & 19,65 \\
\hline - & Minimum & 0,00 & 178,57 & 0,00 & 12,85 \\
\hline - & Maximum & 65,70 & 249,28 & 49,20 & 110,71 \\
\hline \multicolumn{6}{|c|}{ Gejala Depresi } \\
\hline- & Mean & 24,07 & 20,54 & 23,00 & 24,21 \\
\hline - & Std. Deviation & 6,79 & 5,78 & 6,10 & 5,06 \\
\hline - & Minimum & 10,00 & 9,00 & 12,00 & 11,00 \\
\hline- & Maximum & 40,00 & 32,00 & 36,00 & 36,00 \\
\hline \multicolumn{6}{|c|}{ Suasana Hati } \\
\hline - & Mean & 1,56 & 1,62 & 1,68 & 1,59 \\
\hline - & Std. Deviation & 0,29 & 0,33 & ,42 & 0,29 \\
\hline - & Minimum & 0,95 & 0,95 & 1,10 & 1,00 \\
\hline - & Maximum & 2,20 & 2,25 & 2,80 & 2,00 \\
\hline \multicolumn{6}{|c|}{ Vitalitas } \\
\hline - & Mean & 49,33 & 54,81 & 52,67 & 51,07 \\
\hline- & Std. Deviation & 12,85 & 6,85 & 13,82 & 9,06 \\
\hline - & Minimum & 25,00 & 40,00 & 20,00 & 30,00 \\
\hline - & Maximum & 70,00 & 70,00 & 80,00 & 65,00 \\
\hline
\end{tabular}


Tabel 2

Pengaruh Pemberian Buah Terhadap Skor Gejala Depresi, Suasana Hati dan Vitalitas

\begin{tabular}{|c|c|c|c|c|}
\hline \multicolumn{2}{|c|}{ Gejala Depresi, Suasana Hati dan Vitalitas } & Mean & SD & $p$-value \\
\hline $\begin{array}{l}\text { Gejala Der } \\
\text { Kelompok } \\
\text { Perlakuan }\end{array}$ & $\begin{array}{l}\text { Pretest } \\
\text { Posttest }\end{array}$ & $\begin{array}{l}24,36 \\
20,53\end{array}$ & $\begin{array}{c}6,29 \\
12,04\end{array}$ & 0,02 \\
\hline $\begin{array}{l}\text { Kelompok } \\
\text { Kontrol }\end{array}$ & $\begin{array}{l}\text { Pretest } \\
\text { Posttest }\end{array}$ & $\begin{array}{l}23,14 \\
24,21\end{array}$ & $\begin{array}{c}6,24 \\
5,06\end{array}$ & 0,351 \\
\hline Delta & $\begin{array}{l}\text { Perlakuan } \\
\text { Kontrol }\end{array}$ & $\begin{array}{c}-4,38 \\
0,53\end{array}$ & $\begin{array}{l}5,24 \\
7,21\end{array}$ & 0,006 \\
\hline $\begin{array}{l}\text { Suasana } \\
\text { Kelompok } \\
\text { Perlakuan }\end{array}$ & $\begin{array}{l}\text { Pretest } \\
\text { Posttest }\end{array}$ & $\begin{array}{l}1,50 \\
1,62\end{array}$ & $\begin{array}{l}0,25 \\
0,33\end{array}$ & 0,101 \\
\hline $\begin{array}{l}\text { Kelompok } \\
\text { Kontrol }\end{array}$ & $\begin{array}{l}\text { Pretest } \\
\text { Posttest }\end{array}$ & $\begin{array}{l}1,67 \\
1,58\end{array}$ & $\begin{array}{l}0,42 \\
0,29\end{array}$ & 0,220 \\
\hline Delta & $\begin{array}{l}\text { Perlakuan } \\
\text { Kontrol }\end{array}$ & $\begin{array}{c}0,11 \\
-0,09\end{array}$ & $\begin{array}{l}0,33 \\
0,41\end{array}$ & 0,046 \\
\hline $\begin{array}{l}\text { Vitalitas } \\
\text { Kelompok } \\
\text { Perlakuan }\end{array}$ & $\begin{array}{l}\text { Pretest } \\
\text { Posttest }\end{array}$ & $\begin{array}{l}49,23 \\
54,80\end{array}$ & $\begin{array}{c}13,17 \\
6,85\end{array}$ & 0,028 \\
\hline $\begin{array}{l}\text { Kelompok } \\
\text { Kontrol }\end{array}$ & $\begin{array}{l}\text { Pretest } \\
\text { Posttest }\end{array}$ & $\begin{array}{l}51,43 \\
51,07\end{array}$ & $\begin{array}{c}13,46 \\
9,06\end{array}$ & 0,919 \\
\hline Delta & $\begin{array}{l}\text { Perlakuan } \\
\text { Kontrol }\end{array}$ & $\begin{array}{l}5,58 \\
-0,36\end{array}$ & $\begin{array}{l}12,19 \\
18,40\end{array}$ & 0,172 \\
\hline
\end{tabular}

Skor Gejala Depresi, Suasana Hati (Mood) dan Vitalitas pada Responden Sebelum dan Sesudah Intervensi

\section{Analisis Bivariat Gejala Depresi, Suasana Hati (Mood) dan Vitalitas}

Skor gejala depresi, suasana hati (mood) dan vitalitas sebelum dan sesudah diberikannya intervensi buah pada kelompok perlakuan dan kelompok kontrol dianalisis menggunakan uji paired (dependen) sample t-test lalu uji statistik Independen seperti yang terlihat di Tabel 2. Hasil analisis perbedaan menunjukkan bahwa terdapat perbedaan signifikan rata-rata skor gejala depresi pretest dan posttest pada kelompok perlakuan yaitu dari nilai pretest sebesar 24,36 $\pm 6,29$ mengalami penurunan dengan nilai 20.53+12.04 ( $p$-value $=0,02$ ). Sementara itu, rata-rata skor gejala depresi pada kelompok kontrol tidak berbeda signifikan ( $p$-value $=0,351)$. Berdasarkan hasil uji statistik Independen Sample t-test menunjukkan bahwa selisih rata-rata gejala depresi pada kelompok perlakuan dan kelompok kontrol berbeda signifikan $0,006<a(0,05)$. Analisis data ini menunjukkan bahwa pemberian buah mampu menurunkan gejala depresi secara signifikan. Untuk analisis bivariat pengaruh konsumsi buah terhadap suasana hati dapat dilihat di Tabel 2. Terdapat perbedaan rata-rata suasana hati (mood) pretest dan posttest pada kelompok perlakuan dengan rata-rata skor suasana hati (mood) pada kelompok perlakuan mengalami peningkatan yaitu pada pretest sebesar $1,50 \pm 0,25$ menjadi $1,62 \pm 0,33$ pada posttest meskipun tidak signifikan ( $p$-value $=0,101$ ). Sebaliknya, pada kelompok kontrol rata-rata skor suasana hati (mood) mengalami penurunan dari 1,67 $\pm 0,42$ menjadi $1,57 \pm 0,29$ pada posttest meskipun juga tidak signifikan ( $p$ value $=0,220)>a(0,05)$ maka Ho diterima, artinya tidak ada perbedaan skor suasana hati (mood) sebelum intervensi dan sesudah intervensi (pemberian buah) pada kelompok kontrol.Berdasarkan hasil uji statistik independen sample t-test menunjukkan bahwa selisih rata-rata suasana hati (mood) pada kelompok perlakuan sebesar $-0,11 \pm 0,328$ dan pada kelompok kontrol mempunyai selisih ratarata sebesar $0,09 \pm 0,406$ dengan $p$-value 
sebesar $0,046<a(0,05)$ maka Ho ditolak, artinya ada perbedaan suasana hati (mood) pada kelompok perlakuan dan kontrol. Data ini mendemonstrasikan bahwa analisis independent menunjukkan pemberian buah mampu secara signifikan memperbaiki suasana hati.

Indikator vitalitas menunjukkan ada perbedaan rata-rata vitalitas pretest dan posttest pada kelompok perlakuan yaitu dari $49,23+13,17$ menjadi $54,80 \pm 6,85$ ( $p$-value < $0,05)$. Sementara, skor vitalitas pada kelompok kontrol tidak jauh berbeda antara pretest $(51,43 \pm 13,46)$ dan posttest $(51,07 \pm 9,06)$ dengan nilai $p$-value $=0,919>a(0,05)$ maka Ho diterima, artinya tidak ada perbedaan skor vitalitas sebelum intervensi dan sesudah intervensi (pemberian buah) pada kelompok kontrol. Uji statistik independen sample t-test menunjukkan bahwa tidak ada perbedaan signifikan selisih rata-rata skor vitalitas pada kelompok perlakuan sebesar $-5,58 \pm 12,19$ dan pada kelompok kontrol mempunyai selisih ratarata sebesar 0,36 $\pm 18,40$ dengan $p$-value 0,172. Data ini menunjukkan tidak ada perbedaan perbedaan vitalitas pada kelompok perlakuan dan kontrol jika diuji secara independent. Namun, uji dependen menunjukkan bahwa pemberian buah mampu meningkatkan vitalitas.

\section{BAHASAN}

Sejauh ini masih belum ada penelitian di Indonesia yang mengidentifikasi pengaruh konsumsi buah terhadap kesehatan mental remaja putri. Skor rerata gejala depresi menunjukkan bahwa remaja putri usia 15-17 tahun di asrama ini mengalami depresi (skor rerata lebih dari 16) bahkan setelah diberikan intervensi. Remaja merupakan periode kritis perkembangan anak menjadi dewasa, pada saat ini terjadi perkembangan hormonal, fisik, psikologis, sosial yang cepat dan kesehatan remaja yang memiliki dampak besar pada kehidupan selanjutnya. ${ }^{1-2}$ Oleh karena itu, usia muda 15-24 tahun, sangat rentan mengalami gangguan depresi. ${ }^{29}$ Kondisi ini juga didukung bahwa semua sampel dalam penelitian ini adalah penghuni asrama.

Dalam penelitian ini rata-rata sampel kurang mengonsumsi buah untuk memenuhi kebutuhan harian yaitu kurang dari 150 gram/hari. Selama proses intervensi pemberian buah dikategorikan baik dalam kepatuhan intervensi. Terdapat buah yang kurang disukai oleh responden yaitu belimbing, menurut beberapa responden belimbing mempunyai rasa yang aneh dan tidak terbiasa mengonsumsi buah tersebut. Dengan pemberian buah sebanyak 2 porsi/hari terdapat perubahan yaitu penurunan signifikan sebesar 14,47 persen skor gejala depresi pada posttest kelompok perlakuan meskipun masih dalam kategori yang sama yaitu depresi. Beberapa peneliti telah menunjukkan hasil psikologis yang lebih optimal terkait dengan konsumsi buah segar, sayuran mentah atau salad. ${ }^{30} \mathrm{Hal}$ tersebut sejalan dengan penelitian Bishwajit et al. yang dilakukan di Asia Selatan, penelitian tersebut mengenai konsumsi buah dan variabel gejala depresi yang diikuti selama satu tahun satu bulan mengemukakan bahawa mereka yang mengkonsumsi buah segar lebih dari 1,5 porsi dapat mengurangi kejadian gejala depresi sebesar 32 persen $(A O R=0,67 ; 95 \% \mathrm{Cl}=0,44$ $1,30) .{ }^{31}$ Penelitian lainnya yang sependapat adalah Smith and Rogers (2014) yang mengungkapkan bahwa hasil skor depresi yang lebih rendah pada sampel yang diberikan buah sebelum dan sesudah intervensi. ${ }^{18}$ McMartin (2013) pada studi cross-sectional di Kanada juga mendukung penelitian ini yaitu konsumsi buah yang lebih banyak secara signifikan menurunkan gejala depresi (OR: 0,72; $95 \% \mathrm{Cl}$ : $0,71-0,75) .{ }^{17}$ Kondisi depresi dipengaruhi oleh neurotransmitter otak yaitu noradrenalin, dopamine, dan serotonin. ${ }^{20}$ Buah-buahan mengandung vitamin $\mathrm{C}, \mathrm{B} 6, \mathrm{~B} 9$ dan $\mathrm{B} 12$ yang merupakan prekursor homosistein yang dapat mempengaruhi depresi dan suasana hati dan kesehatan mental lainnya. 21-23,32

Suasana hati (mood) adalah perasaan yang berlangsung sementara atau dalam jangka pendek. Pada gangguan jangka panjang, suasana hati (mood) yang buruk dapat mengakibatkan depresi. ${ }^{33}$ Suasana hati (mood) dapat mempengaruhi cara-cara dimana individu tersebut berfikir dan bertindak. Suasana hati bisa datang kapan saja, orang satu jam sebelumnya masih bisa tertawa, bercanda, dan sangat antusias untuk berbicara kemudian menjadi pendiam sepanjang hari tanpa ada alasan yang jelas atau masalah lain yang mempengaruhi suasana hatinya. ${ }^{34}$ Berdasarkan teori yang ada suasana hati pada saat pagi hari orang-orang mempunyai semangat yang seiring 
berjalannya hari suasana hati cenderung meningkat dan kemudian menurun pada malam hari, oleh karena itu pengisian kuesioner dilakukan pada malam hari sebelum tidur..$^{35} \mathrm{Hal}$ tersebut sejalan dengan penelitian Brookie et al (2017) yaitu pengambilan data suasana hati (mood) dilakukan pada jam 19.00 - 01.00 malam. Suasana hati berkaitan dengan konsumsi vitamin C. Vitamin C berperan sebagai kofaktor untuk enzim dopamin-betahydroxylase untuk mengubah dopamin menjadi norepinefrin yang memainkan peran penting dalalm pengaturan suasana hati. Vitamin $C$ sendiri banyak terdapat di buah. .11,32 Vitamin B6, B12, dan B9 yang terdapat dalam buah merupakan prekursor yang menyebabkan penurunan homosistein yang tidak hanya mempengaruhi depresi tetapi juga suasana hati dan kesehatan mental lainnya. ${ }^{22,23}$ Dalam penelitian ini, uji dependen menunjukkan tidak ada perbedaan yang signifikan antara pretest dan posttest skor suasana hati (mood) pada kelompok perlakuan ataupun kontrol, meskipun terdapat peningkatan pada skor posttest kelompok perlakuan. Sementara uji independent menunjukkan ada perbedaan signifikan, dimana kelompok perlakuan menunjukkan perbaikan suasana hati. Penelitian kami sejalan dengan penelitian McMartin (2013) yaitu mereka yang memiliki konsumsi buah yang tinggi memiliki perbaikan mood yang signifikan dengan $p$ $<0,05 .{ }^{17} \quad$ Penelitian Richard (2015) mengungkapkan bahwa responden yang memenuhi rekomendasi konsumsi buah yaitu sebanyak 2 porsi/hari selama 5 hari memiliki nilai gangguan mood yang rendah dibanding mereka yang mengkonsumsi kurang dari 2 porsi (OR: 0,83; 95\% Cl: 0,74-0,9). ${ }^{36}$

Pegukuran vitalitas berhubungan dengan jumlah dari energi dan rasa lelah yang dimiliki oleh masing-masing individu. Pengukuran vitalitas pada penelitian ini menggunakan kuesioner SF-36 dengan mengambil skala 4 item pada komponen energy/fatigue. Vitalitas adalah perasan subyektif, perasaan yang benar-benar hidup, bersemangat, atau penuh energi dan antusiasme untuk hidup. Konsep vitalitas mengacu pada keadaan perasaan hidup dan waspada dan memiliki energi yang tersedia. Vitalitas dianggap sebagai aspek kesejahteraan..$^{37,27}$ Penelitian ini menunjukkan bahwa skor kelompok perlakuan saat pretest dan posttest mengalami peningkatan signifikan.
Hasil penelitian ini sejalan dengan penelitian Brookie (2017) yaitu terjadi peningkatan vitalitas setelah pemberian intervensi sayur dan buah. ${ }^{19}$ Namun, uji statistik independen t-test menunjukkan tidak ada perbedaan selisih vitalitas pada kelompok perlakuan dan kontrol. Faktor yang dapat menyebabkannya hal tersebut salah satunya adalah kepribadian dari responden itu sendiri. ${ }^{11}$

\section{SIMPULAN DAN SARAN}

\section{Simpulan}

Pemberian buah sebanyak 150 gram/harinya atau 2 porsi sehari pada remaja putri mampu memperbaiki gejala depresi, suasana hati dan vitalitas. Perlu upaya untuk memenuhi kebutuhan konsumsi buah pada remaja putri terutama yang memiliki keterbatasan dalam pemenuhan konsumsi buah sehingga mampu mengurangi risiko gangguan mental emosional yang menganggu produktivitas remaja putri.

\section{Saran}

Untuk penelitian selanjutnya diperlukan waktu intervensi lebih lama untuk dapat melihat perubahan lebih berdampak dari suasana hati serta vitalitas. Selain itu, perlu pengkajian faktor lain yang mempengaruhi gejala depresi, suasana hati serta vitalitas seperti kepribadian dan riwayat gangguan mental sebelumnya.

\section{UCAPAN TERIMAKASIH}

Terima kasih kepada remaja putri Pondok Pesantren Assidiqiyah Pusat, Jakarta yang telah berpartisipasi dalam penelitian kami.

\section{RUJUKAN}

1. Mubasyiroh R, Suryaputri IY, Tjandrarini $\mathrm{DH}$. Determinan Gejala Mental Emosional Pelajar SMP-SMA di Indonesia Tahun 2015. Indonesian Bulletin of Health Research. 2017;45(2):103-12.

2. Yusuf NR. Emotional Problems in High School Students in Jakarta. KnE Life Sciences. 2018 Jan 11:165-74. 
3. Kemenkes RI. Hasil Utama Riset Kesehatan Dasar Tahun 2018. Kementrian Kesehat Republik Indones. 2018;

4. Kemenkes RI. Peran Keluarga Dukung Kesehatan Jiwa Masyarakat [Internet]. Depkes. 2016. Available from: https://www.kemkes.go.id/article/print/1 6100700005/peran-keluarga-dukungkesehatan-jiwa-masyarakat.html

5. Sanvina Arsita A, Fanani HM, Dasuki MS. Perbedaan Tingkat Depresi Siswa Putri Kelas XI Di Pondok Pesantren AlMukmin Dengan Di SMA Negeri 2 Sukoharjo (Doctoral dissertation, Universitas Muhammadiyah Surakarta).

6. YS K, Prakash B, Kulkarni P, Narayanamurthy MR. Prevalence and factors associated with depression and anxiety among students of backward community and minority girl's hostels of Mysuru city. International Journal of Community Medicine and Public Health. 2018 Mar;5(3):1075.

7. Septiana, A I. Deskripsi Penyesuaian Diri Penghuni Asrama. Program Studi Psikologi. Jurusan Psikologi Fakultas Psikologi. Yogyakarta: Universitas Sanata Dharma.; 2017.

8. Wuon AS, Bidjuni $H$, Kallo V. Perbedaan tingkat depresi pada remaja yang tinggal di rumah dan yang tinggal di panti asuhan bakti mulia karombasan kecamatan Wanea Manado. Jurnal Keperawatan. 2016 Nov 3;4(2).

9. Robbins SP, Judge TA. Perilaku Organisasi Buku 1, Jakarta: Salemba Empat. Hal. 2008;256:266.

10. Hasler G. Pathophysiology of depression: do we have any solid evidence of interest to clinicians?. World Psychiatry. 2010 Oct;9(3):155.

11. Kurnianto 0 . Perubahan tingkat depresi berdasarkan asupan vitamin B6, B9, B12, dan Omega-3 pada pasien skizofrenia di Rumah Sakit Jiwa Dr. Soeharto Heerdjan Jakarta Tahun 2018. J Chem Inf Model. 2018;

12. Kementerian Kesehatan. Pedoman Gizi
Seimbang. Peraturan Menteri Kesehatan Republik Indonesia Nomor 41 tentang Pedoman Gizi Seimbang 2014.

13. Oyebode O, Gordon-Dseagu V, Walker $A$, Mindell JS. Fruit and vegetable consumption and all-cause, cancer and CVD mortality: analysis of Health Survey for England data. J Epidemiol Community Health. 2014 Sep 1;68(9):856-62.

14. Crowe FL, Roddam AW, Key TJ, Appleby PN, Overvad K, Jakobsen MU, Tjønneland A, Hansen L, Boeing $H$, Weikert C, Linseisen J. Fruit and vegetable intake and mortality from ischaemic heart disease: results from the European Prospective Investigation into Cancer and Nutrition (EPIC)-Heart study. European heart journal. 2011 May 1;32(10):1235-43.

15. Bellavia A, Larsson SC, Bottai M, Wolk $A$, Orsini N. Fruit and vegetable consumption and all-cause mortality: a dose-response analysis. The American journal of clinical nutrition. 2013 Aug 1;98(2):454-9.

16. Carr AC, Bozonet SM, Pullar JM, Vissers MC. Mood improvement in young adult males following supplementation with gold kiwifruit, a high-vitamin C food. Journal of Nutritional Science. 2013;2.

17. McMartin SE, Jacka FN, Colman I. The association between fruit and vegetable consumption and mental health disorders: evidence from five waves of a national survey of Canadians. Preventive medicine. 2013 Mar 1;56(34):225-30.

18. Smith AP, Rogers R. Positive effects of a healthy snack (fruit) versus an unhealthy snack (chocolate/crisps) on subjective reports of mental and physical health: A preliminary intervention study. Frontiers in nutrition. 2014 Jul 16;1:10.

19. Brookie KL, Mainvil LA, Carr AC, Vissers MC, Conner TS. The development and effectiveness of an 
ecological momentary intervention to increase daily fruit and vegetable consumption in low-consuming young adults. Appetite. 2017 Jan 1;108:32-41.

20. Kaplan, H.I., Sadok, B. J and GJA. Sinopsis Psikiatri: IImu Pengetahuan Perilaku Psikiatri Klinis. Jilid satu. Dr. I Made. Jakarta: Bina Rupa Aksara; 2010. 113-129, 149, 183 p.

21. Sunita A. Prinsip dasar ilmu gizi. Jakarta: Gramedia Pustaka Utama; 2009. 51-75 p.

22. Lim SY, Kim EJ, Kim A, Lee HJ, Choi $\mathrm{HJ}$, Yang SJ. Nutritional factors affecting mental health. Clinical Nutrition Research. 2016 Jul 1;5(3):143-52.

23. Nguyen B, Ding D, Mihrshahi S. Fruit and vegetable consumption and psychological distress: cross-sectional and longitudinal analyses based on a large Australian sample. BMJ open. 2017 Mar 1;7(3).

24. Kemenkes RI. Badan Penelitian Dan Pengembangan Kesehatan Kementrian Kesehatan RI. Ris Kesehat Dasar. 2007;

25. Badan Penelitian dan Pengembangan Kesehatan. Riset Kesehatan Dasar (RISKESDAS) 2013. Lap Nas 2013. 2013;

26. Santoso B, Sulistiowati E, Fajarwati T, Pambudi LEMBAGA PENERBIT BADAN PENELITIAN DAN PENGEMBANGAN KESEHATAN J, Kata Pengantar I. Studi Diet Total: Survei Konsumsi Makanan Individu Provinsi Jawa Tengah 2014. Badan Penelitian dan Pengembangan Kesehatan. 2014.

27. Roberts RE, Andrews JA, Lewinsohn PM, Hops H. Assessment of depression in adolescents using the Center for Epidemiologic Studies Depression Scale. Psychological Assessment: A Journal of Consulting and Clinical Psychology. 1990 Jun;2(2):122.

28. Huebner ES, Dew T. Preliminary validation of the positive and negative affect schedule with adolescents.
Journal of Psychoeducational Assessment. 1995 Sep;13(3):286-93.

29. Fitriani A, Hidayah N. Kepekaan humor dengan depresi pada remaja ditinjau dari jenis kelamin. Humanitas: Jurnal Psikologi Indonesia. 2012 Apr 26;9(1):76-89.

30. El Ansari W, Suominen S, BergBeckhoff G. Mood and food at the University of Turku in Finland: nutritional correlates of perceived stress are most pronounced among overweight students. International journal of public health. $2015 \operatorname{Sep}$ 1;60(6):707-16.

31. Bishwajit G, O'Leary DP, Ghosh S, Sanni $Y$, Shangfeng $T$, Zhanchun $F$. Association between depression and fruit and vegetable consumption among adults in South Asia. BMC psychiatry. 2017 Dec 1;17(1):15.

32. Gupta P, Tiwari S, Haria J. Relationship Between Depression and Vitamin C Status: A Study on Rural Patients From Western Uttar Pradesh in India. Int $\mathrm{J}$ Sientific Study. 2014;

33. Roberts J. Low mood and depression in adolescence: clinical update. British Journal of General Practice. 2013 May 1;63(610):273-4.

34. Fauziah S. Pengaruh religiusitas dan suasana hati (mood) terhadap kinerja karyawan Ayam Geprak Mak Sunah Madiun. Dr Diss Univ Islam Negeri Maulana Malik Ibrahim [Internet]. 2017; Available from: https://docplayer.info/84042315-

Pengaruh-religiusitas-dan-suasana-hatimood-terhadap-kinerja-karyawan-ayamgeprak-mak-sunah-madiun.html

35. Flood G. Davis, Richard $H_{\text {., }}$ Worshipping Śiva in Medieval India. Ritual in an Oscillating Universe. Delhi: Motilal Banarsidass 2000, pp. xvi, 200. ISBN 81-208-1747-8. Rs 295,-. IndoIranian Journal. 2005 Jan 1;48(12):142-5.

36. Richard A, Rohrmann S, Vandeleur CL, Mohler-Kuo M, Eichholzer M. Associations between fruit and 
vegetable consumption and psychological distress: results from a population-based study. BMC psychiatry. 2015 Dec 1;15(1):213.37. Ryan RM, Deci EL. On happiness and human potentials: A review of research on hedonic and eudaimonic well-being. Annual review of psychology. 2001 Feb;52(1):141-66. 